\title{
ARTIKKELIT
}

\section{Vanhuksen oikeus hoivaan ja omaisolettama}

\author{
Laura Kalliomaa-Puha ${ }^{1}$
}

${ }^{1}$ Yhteiskuntatieteiden tiedekunta, Tampereen yliopisto

\begin{abstract}
Jokaisella vanhuksella on Suomessa yksilöllinen, viime kädessä perustuslaissa taattu, oikeus riittävään hoivaan ja huolenpitoon. Silti tämä oikeus on usein käytännössä riippuvainen siitä, onko vanhalla ihmisellä omaisia tukenaan. Tässä artikkelissa tarkastellaan sitä, miten oikeus hoivaan ja hoitoon taataan lainsäädännössä. Omaisilla ei lain mukaan ole vastuuta hoivan järjestämisestä, mutta silti lainsäädäntö monessa kohdin ikään kuin olettaa omaisten olevan vanhuksen tukena. Vaikka omaiset usein ovatkin tukena, miten perusoikeus hoivaan ja huolenpitoon toteutuu niillä vanhuksilla, joilla ei ole omaisia? Artikkeli nostaa vakavimpana omaisolettaman riskinä esiin ne vanhukset, joilla on omaisia, mutta joiden omaiset eivät voi, osaa tai halua auttaa.
\end{abstract}

\section{Johdanto}

Suomessa sosiaaliset oikeudet ovat yksilöllisiä oikeuksia, joihin omaisten olemassa ololla tai avuntarvitsijan tai hänen omaistensa sosioekonomisella asemalla ei pitäisi olla vaikutusta. Suomen lainsäädäntö takaa yksilöllisen oikeuden hoivaan ja huolenpitoon vanhuksille, jotka eivät sellaista pysty itse hankkimaan. Vanhusten hoiva sisällytetään yleensä sosiaalihuoltoon. Hoiva on sosiaalilainsäädännössä kuvattu usein tavalla, johon sisältyy harkinnanvaraisia elementtejä. Siksi oikeus hoivaan on vaikea näyttää eikä sitä useinkaan pidetä kovin vahvana oikeutena. Vanhuksen oikeutta huolenpitoon on arvioitu kansainvälisten ihmisoikeussopimusten valossa (Kalliomaa-Puha 2007, 47-58; Mikkola 2014, 46, 63-66), terveydenhuollon näkökulmasta (Kotkas 2014;
Lohiniva-Kerkelä 2014) ja mietitty parantavatko lakiin kirjatut määräajat vanhuksen oikeuksien toteutumista (Karvonen-Kälkäjä 2017). Vanhuksen oikeutta hoivaan ei sen sijaan ole juurikaan pohdittu tämän oikeuden vahvuuden näkökulmasta (ks. kuitenkin Kalliomaa-Puha \& Kangas 2015). Tässä sosiaalioikeuden alaan kuuluvassa artikkelin ensimmäisessä osassa osoitetaan Kaarlo Tuorin sosiaalisten oikeuksien luokittelua apuna käyttäen (Tuori 2005; Tuori \& Kotkas 2016), että viime kädessä vanhuksen oikeus huolenpitoon on taattu lainsäädännössämme subjektiivisena oikeutena.

Arkikokemuksen mukaan oikeus hoivaan ei kuitenkaan käytännössä aina toteudu ilman apua. Lainsäädäntömme ei silti velvoita omaisia tällaista apua antamaan. Artikkelin toinen osa paneutuu tähän ristiriitaan, tarkemmin sanoen, eri normeihin kirjoitettuun olettamaan 
siitä, että omaiset auttavat vanhuksia saamaan etuuksia ja palveluja. Omaisolettama ilmenee paitsi yksittäisissä pykälissä ja niiden tulkinnoissa, myös järjestelmätasolla. Vanhustenhuolto on monimutkainen järjestelmä ja haastaa omaiset auttamaan, kun etsitään sopivaa palvelua, haetaan sitä, yhteen sovitetaan saatuja palveluja, arvioidaan palvelujen laatua tai kun mahdollisesti haetaan oikeusturvaa jälkikäteen. On myös tärkeää kysyä, millaisissa tilanteissa tällainen omaisolettama vaarantaa vanhuksen oikeuden saada perustuslaissa heille taatun hoivan?

\section{Oikeus hoivaan}

Viime kädessä oikeus hoivaan turvataan Suomen perustuslaissa (731/1999). Sen 19 §:ssä luvataan turvata välttämätön toimeentulo ja huolenpito jokaiselle, joka ei itse kykene näitä turvaamaan. Huolenpidon pitäisi olla sellaista, jolla taataan ihmisarvoisen elämän edellytykset. Vaikka "ihmisarvoinen elämä" on monitulkintainen ja ajassa muuttuva käsite, perustuslain esitöistä voi päätellä, että juuri vanhustenhuollon palvelut ovat niitä palveluita, jotka ovat takaamassa ihmisarvoista elämää. ${ }^{1}$

Sosiaalihuollon lainsäädännössä määritellään tarkemmin, mitä tämä lupaus käytännössä tarkoittaa. Vanhustenhuollon palveluista säädetään monissa laeissa. Melko tuore vanhuspalvelulaki (laki ikääntyneen väestön toimintakyvyn tukemisesta sekä iäkkäiden sosiaali- ja terveyspalveluista 980/2012) velvoittaa huolehtimaan vanhusten hyvinvointia edistävistä palveluista, mutta varsinaisia hoivalupauksia vanhuspalvelulaissa ei ole. Se ennemminkin kokoaa yhteen aikaisempia säännöksiä, jotka ovat olleet hajallaan sosiaalihuoltoa koskevissa laeissa (ks.

Perustuslain muuttamista koskeva hallituksen esitys toteaa, että "nykyisistä tukijärjestelmistä turvaavat ihmisarvoisen elämän perusedellytyksiä eräät lasten, vanhusten, vammaisten ja kehitysvammaisten huoltoon kuuluvat tukitoimet (HE 309/1993, 79). esim. Arajärvi 2014,265). Siksi nämä muutkin lait ovat edelleen merkityksellisiä. Esimerkiksi moni palvelu määritellään sosiaalihuoltolaissa (1301/2014). Myös laki sosiaalihuollon asiakkaan oikeuksista (812/2000, asiakaslaki), joka nimensä mukaisesti kertoo asiakkaan oikeuksista, asiakkaan kohtelusta ja menettelystä sosiaalihuollossa, on tärkeä yleislaki vanhustenhuollossa. ${ }^{2}$ Yksilöllisen tarpeensa mukaisesti vanhus voi myös tarvita esimerkiksi vammaispalvelulaissa (380/1987) tai päihdehuoltolaissa (41/1986) määriteltyjä palveluja.

Vanhuksen näissä laeissa määritelty oikeus sosiaaliturvaan on eri vahvuista. Joissakin tapauksissa vanhuksella on oikeus vaatia tiettyä palvelua tai etuutta, toisissa taas kunnalla on oikeus päättää siitä, järjestetäänkö palvelua ylipäätään. Etuudet ja palvelut voidaan Kaarlo Tuorin mukaan luokitella subjektiivisiin oikeuksiin ja muihin kuin subjektiivisiin oikeuksiin. Jälkimmäiset voidaan edelleen jakaa määrärahasidonnaisiin oikeuksiin sekä kunnan vapaaehtoisesti järjestämiin palveluihin ja etuuksiin (Tuori 2005, 188-191; Tuori \& Kotkas 2016, 294-296).

Tutuin esimerkki subjektiivisesta oikeudesta on alle kouluikäisen lapsen oikeus (osapäiväiseen) päivähoitoon, mutta itse asiassa subjektiivisia oikeuksia on muitakin. Subjektiiviselle oikeudelle on tyypillistä, että jos kriteerit täyttyvät, niin viranomaisen on myönnettävä etuus tai palvelu riippumatta siitä onko etuuteen tai palveluun varattua määrärahaa jäljellä. Toisaalta mitä epämääräisemmin saamisedellytykset tai etuuden sisältö on kuvattu, sitä

\footnotetext{
2 Vanhus on usein myös terveydenhuollon asiakas, jolloin potilaan oikeudet kokoava potilaslaki (785/1992) sekä terveydenhuollon yleislaki, terveydenhuoltolaki (1326/2010), ovat keskeisiä. Jos palvelua ei saada tai palveluun ollaan tyytymättömiä, säännöt etukäteisestä ja jälkikäteisestä oikeusturvasta sosiaali- ja terveydenhuollossa tulevat tärkeiksi (ks. esim. sosiaalihuoltolaki, asiakaslaki, potilaslaki, hallintolaki 434/2004 ja hallintolainkäyttölaki 586/1996). Tässä artikkelissa keskitytään kuitenkin sosiaalihuollon piiriin kuuluvaan hoivaan, eikä varsinaisesti pohdita terveydenhuoltoa tai muutoksenhakua.
} 
enemmän vaihtelua voi esiintyä. Subjektiivisina oikeuksina taatut oikeudet ovat sitä vahvempia mitä täsmällisemmin niiden saamisedellytykset ja sisältö on lainsäädännössä määritelty. (Tuori \& Kotkas 2016, 296.) Vanhusten toimeentuloetuudet on pitkälti turvattu selkeästi subjektiivisina oikeuksina. Jos ihminen on oikeutettu eläkkeeseen tai täyttää eläkettä saavan hoitotuen kriteerit, etuus on maksettava. Tällaiset standardoidut toimeentuloturvaetuudet ovat subjektiivisia etuuksia. Vastaavasti tulosidonnaiset toimeentuloturvaetuudet ovat subjektiivisia oikeuksia. Kun asumistuen edellytykset täyttyvät, on asumistuki myönnettävä.

Lisäksi monet kunnalliset palvelut voivat olla subjektiivisia oikeuksia. Kun laissa määritelty tarve palvelulle on syntynyt ja näytetty, niin palvelua on annettava niin, että tarve tyydyttyy. Lapsen oikeus päivähoitoon on helppo todeta riidattomasti, päivähoidon sisällöstä voidaan sen sijaan keskustella. Myös vammaispalveluissa on monia palveluita, jotka on määritelty niin tarkasti, että oikeuden subjektiivinen luonne on helppo havaita: normit on kirjoitettu kaavalla " a:lla on b:tä kohtaan oikeus c:hen" (Tuori \& Kotkas 2016, 294). Silloin kun palveluun pääsyn kriteereitä ei ole määritelty kovin täsmällisesti, ei palveluja osata pitää subjektiivisina oikeuksina. Vanhusten palvelut ovat lähes aina tällaisella harkintaa edellyttävällä, harmaalla alueella, ja siksi oikeus hoivaan on usein vaikea todentaa. Kriteerit hoivan piiriin pääsylle on kirjoitettu siten, että niihin sisältyy paljon harkintavaltaa. Tämä ei vielä tarkoita, etteikö oikeus voisi olla subjektiivinen. Sosiaalihuollon sisältöä onkin usein lähes mahdotonta säännellä ehdottomin ja tarkkarajaisin normein ilman, että järjestelmästä tulee liian jäykkä. Mallia lasten oikeudesta päivähoitoonkaan ei voi ottaa, sillä vanhuudessa toimintakyvyn puutteet eivät ole yhteydessä tiettyyn ikään. Ammattilaiselle jätetyn harkintavallan on tarkoitus varmistaa, että palvelut ovat joustavia, tarkoituksenmukaisia ja siten yksilön tarpeita vastaavia. Normeihin jätetty harkintavalta pitää kuitenkin aina sisällään myös riskin - väljä normi jättää tilaa myös harkintavallan väärinkäytölle. (Ks. harkintavallasta Rajavaara 2014.) Esimerkiksi vanhuspalvelulain 13 §:ssä todetaan, että "palvelut on toteutettava niin, että ne tukevat iäkkään henkilön hyvinvointia, terveyttä, toimintakykyä, itsenäistä suoriutumista ja osallisuutta”. Sosiaalihuoltolain $21 \S$ kertoo, että tehostettua palveluasumista järjestetään "henkilöille, joilla hoidon ja huolenpidon tarve on ympärivuorokautista”. Kunnalle jää harkinnanvaraa tulkita miten hyvinvointia tuetaan tai millainen hoivan tarve on tosiasiallisesti ympärivuorokautista. Harkintavallan riskejä on pyritty etukäteen rajaamaan erilaisilla ohjeilla ja laatusuosituksilla. Käytännössä kuntien omat soveltamisohjeet ovat hyvin tärkeitä. Parhaimmillaan ne selkeyttävät ja yhdenmukaistavat vanhusten kohtelua. Pahimmillaan kuntien ohjeet jäykistävät tulkinnat niin, ettei yksilöllistä harkintaa tehdä lainkaan ja vanhuksen yksilölliset tarpeet jäävät huomiotta. Esimerkiksi ohjeet, joissa palvelu varataan kategorisesti jollekin ryhmälle ilman yksilöllistä harkintaa, on oikeuskäytännössä todettu laittomiksi (esim. Hämeenlinnan hallintooikeus 22.5.2002 02/0249/4 ja Turun hallintooikeus 25.1.2012 01751/11/6110).

Julkinen vastuu hoivasta voi toteutua myös siten, että palvelut hankitaan ensin itse ja myöhemmin peritään kunnalta kustannukset palvelusta, joka kunnan olisi pitänyt tarjota. Näin on menestyksekkäästi toimittu terveydenhuollossa muutamien korkeimman hallintooikeuden tapauksien mukaan (ks. esim. KHO 2002:21). Sosiaalihuollossa tämä mahdollisuus on hieman epäselvempi, mutta yhtä kaikki tällainen mahdollisuus on tarjolla vain sellaisille vanhuksille, joilla on resursseja maksaa palvelut ensin itse. Esimerkiksi päihdehuollossa on muutaman oikeustapauksen jälkeen tullut selväksi, että jos sopivaa palvelua ei muuten kohtuullisessa ajassa saa todettuun tarpeeseen, sen voi ostaa ja kunta on velvollinen maksamaan kustannukset (KHO 22.9.2000 T 2366; Hämeenlinnan HO 12.7.2004 T 04/0256/4; Hämeen lääninoikeus 3.9.1998 T 430/3; ks. 
lähemmin Poikonen 2017). Asiakkaan vapaata valintaa tämä ei kuitenkaan tarkoita. Esimerkiksi Mikkelin lääninoikeuden tapauksessa asiakkaalle oli ensin tarjottu kuntoutusta kunnan laitoksessa. Asiakas halusi toiseen, yksityiseen laitokseen. Kuntaa ei velvoitettu maksamaan laskua, vaikka asiakkaalla oli tarve hoitoon - hoitoa kun oli tarjottu kunnan laitoksessa eikä asiakas ollut osoittanut, etteikö hoito olisi ollut hänelle soveltuvaa. (Mikkelin lääninoikeus 5.2.1992 56.)

Toisaalta lainsäädännössä on määrärahasidonnaisia sosiaali- ja terveydenhuollon palveluja ja etuuksia. Vaikka tarve onkin olemassa ja myöntökriteerit palvelulle tai etuudelle täyttyvät, ei kunnan tarvitse etuutta tai palvelua myöntää, jos määrärahat ovat loppu. Vanhustenhuollossa paljon keskusteltu esimerkki tästä on omaishoidon tuki. Se kuuluu tällaisiin määrärahasidonnaisiin etuuksiin, joita kunta voi myöntää. Monesti on vaikea ymmärtää, miksi omaishoidon tukea ei myönnetä, vaikka hoidettava on selkeästi palvelun tarpeessa ja hänelle löytyy sopiva ja halukas omaishoitaja ja omaishoitajan avulla järjestetty hoito on monin kerroin laitoshoitoa tai kotiin järjestettyä kunnan hoitoa halvempaa. Lain mukaanhan kunnan on järjestettävä huolenpitoa tarvitsevan hoiva. Kunta saa kuitenkin valita, miten tämän tarpeen täyttää - ja kunnan tuleekin siksi tällaisissa tilanteissa osoittaa vanhukselle muu, hänen tarpeensa täyttävä, etuus tai palvelu.

Sosiaalihuoltolaissa palveluista kirjoitetaan tavallisimmin passiivin indikatiivimuodossa, kuten "annetaan" (kotipalvelua tai laitoshoitoa sosiaalihuoltolain 21 ja 22 §:issä) tai "järjestetään” (liikkumista tukevat palvelut sosiaalihuoltolain 23 §ssä). Tämä sanamuoto jättää valitettavan epäselväksi onko tarkoitus ollut perustaa subjektiivinen oikeus näihin ensi käden palveluihin (Tuori \& Kotkas 2016, 299-300 ja 320; vrt. Arajärvi 2011, 91-93). Kaarlo Tuori ja Toomas Kotkas pitävät ainakin asumispalveluita ja laitospalveluita tietyin edellytyksin subjektiivisina oikeuksina (Tuori \& Kotkas 2016, 320-321, ks. myös HE 164/2014, 115116). Sosiaalihuoltolaista ei vielä ole saatavilla oikeuskäytäntöä,jossa tätä olisi testattu. Vaikka lupaus hoivasta on täten hieman epämääräinen, se on kuitenkin teorian tasolla vahva, subjektiivinen oikeus. Jos palveluita ei ole esimerkiksi sosiaalihuoltolain nojalla tarjolla, viimesijainen huolenpito on järjestettävä perustuslain $19.1 \S$ nojalla.

Kunnat voivat myös järjestää vapaaehtoisesti sosiaali- ja terveyspalveluja. Vanhustenhuollossa tällaisia ovat esimerkiksi virallisten omaishoitajien ja muiden omaisten virkistyspäivät: kunta voi lakisääteisten lomapäivien lisäksi järjestää hoitajille lyhyempiä virkistysvapaita. Lyhyet hengähdystauot ovat toimineet hyvin (ks. esim. Juntunen \& Salminen 2014). Omaishoitaja on päässyt asioille, lääkäriin tai vaikkapa kävelylle sillä aikaa, kun hoidettavasta on pidetty huolta, tyypillisesti kunnan päivätoimintayksikössä. Vanhuksille on myös monessa kunnassa tarjolla omia liikuntapalveluja tai esimerkiksi ilmainen sisäänpääsy kunnan uimahalliin. Tiedetään, että liikunta parantaa vanhusten elämänlaatua ja ennaltaehkäisee monia ikääntymiseen liittyviä vaivoja (ks. esim. Liikunta ja ikääntyminen 2013). Hyvistä kokemuksista huolimatta kunnan ei ole pakko järjestää tällaista palvelua eikä toisaalta kuntalaisella ole mahdollisuutta sellaista vaatia. (Ks. oikeudesta hoitoon tarkemmin Kalliomaa-Puha \& Kangas 2015.)

\section{Omaisolettama}

\section{Perheen vastuu hoivasta}

Lainsäädännön mukaan jokaiselle apua tarvitsevalla vanhukselle tulisi siis olla apua tarjolla. Silti usein käy niin, etteivät vanhukset pääse palveluiden piiriin ilman muiden myötävaikutusta ja apua. On tärkeää kysyä, mikä on perheen rooli vanhustenhuollossa. 
Käytännössä perheen rooli on suuri niin Suomessa kuin muissakin maissa (ks. perheen vastuusta esim. Hoffman \& Rodrigues 2010; Colombo, Llena-Nozal, Mercier \& Tjadens 2011; Vilkko ym. 2014; Van Aerschot 2014; Hoppania ym. 2016; Zechner 2017 tässä teemanumerossa). Lainsäädännössä sen sijaan perheen rooli on Suomessa melko pieni. Aina 1950-luvulle asti perheellä oli konkreettinen vastuu perheenjäsentensä auttamisesta, mikä voitiin laittaa täytäntöön perimällä esimerkiksi laitoshoidon kustannuksia perheeltä. (Vuoden 1879 vaivaishoitoasetus 4 §; 1922 köyhäinhoitolaki 3 §; vuoden 1956 huoltoapulaki 4 §). Tämä on arkipäivää vieläkin monissa maissa. Suomessa tämä käytäntö jäi kuolleeksi kirjaimeksi pikkuhiljaa niin, että 1970-luvulla uusi käytäntö kirjattiin lakiin. Lapset eivät ole juridisesti vastuussa vanhempiensa tai isovanhempiensa elatuksesta ja huolenpidosta eivätkä vanhemmat vastaavasti aikuisten lasten tai lastenlasten huolenpidosta. Suomessa aikuisten kesken ei ole elatus- tai huolenpitovastuuta muuten kuin aviopuolisoiden kesken (avioliittolaki (234/1929) 46 §). Tuomioistuimissa entisen puolison elatusta vaaditaan harvoin ja tuomitaan maksamaan vielä harvemmin (Kangas 2013, 257). Oletus on, että jokainen täysi-ikäinen ja täysivaltainen henkilö elättää itsensä ja hoitaa omat asiansa.

Lainsäädännössä on pitkään puhuttu pelkästään elatuksesta (Rintala 2003). Tämä on jatkumoa siitä, että vanhusten, vammaisten ja pitkäaikaissairaiden huollon painopiste oli aikaisemmin pitkälti rahansiirroissa eikä konkreettisessa huolenpidossa ja hoivassa. Eläkejärjestelmän vakiinnutettua paikkansa ongelmat ovat toiset: yksin asuminen, yksinäisyys ja krooniset sairaudet. Tarvitaan hoivaa. Elatusvastuun ajatellaankin tänä päivänä pitävän sisällään myös tavanomaisen hoivan. Puolisoita ei kuitenkaan katsota voitavan velvoittaa raskaaseen hoivatyöhön - vaikka moni sellaisenkin vastuun haluaa ottaa tai joutuu ottamaan.
Edellä on kirjoitettu juridisesta elatus- ja huolenpitovastuusta. Moraalinen vastuu on toinen asia. Moraalisesta vastuusta kertoo paljon se, että suomalaiset auttavat tutkimusten mukaan varsin paljon omaisiaan, joidenkin tutkimusten mukaan jopa eniten Euroopassa (Kehusmaa 2014, 16). Kun julkinen hoivatarjonta supistuu, perheiden on todettu ottavan entistä suuremman vastuun hoivasta. Ruotsissa erityisesti vanhusten keski-ikäisten tyttärien on havaittu lisänneen apuaan. Ruotsissa on myös havaittu, että näin tekevät erityisesti alemmin koulutetut, työväenluokkaisissa ammateissa työskentelevät, kun puolestaan korkeammin koulutetut perheet paikkaavat julkispalvelujen heikentymistä ostamalla aiempaa enemmän yksityisiä hoivapalveluita (Meagher \& Szhebehly 2013). Vastaava ilmiö on havaittu myös Irlannissa (Timonen 2014) ja Saksassa (Theobald 2011). Perheessä annettava hoiva on myös vahvasti sukupuolisidonnainen (Colombo ym. 2011; Hoppania ym. 2016), mutta se on myös tiiviisti kytköksissä sosioekonomiseen asemaan ja tulotasoon. Suomessakin on merkkejä siitä, että omaiset paikkaavat julkisen hoivan aukkoa - joskus vastentahtoisestikin, muiden vaihtoehtojen puuttuessa (Sointu 2016, 119-132; Kalliomaa-Puha \& Tillman 2016). Perhesuhteet ovat merkityksellisiä, vaikka asuttaisiin kaukana: myös LATsuhteet (living apart together) tai etäomaishoito voivat olla ratkaisevia. Apuun ollaan valmiita tulemaan jopa toisesta maasta, jolloin puhutaan ylirajaisesta hoivasta. (Zechner 2006; Peiponen 2010; Pöllänen 2013; Hoppania ym. 2016.) Avun saaminen usein myös kasautuu. Lina Van Aerschotin mukaan ne, jotka saivat omaisten apua, saivat todennäköisemmin kunnallista apua ja käyttivät yksityisiä palveluja: kunnallisen avun piirissä olevat saivat myös omaisten apua ja käyttivät yksityisiä palveluja, ja yksityisiä palveluja käyttävät saivat omaisten apua ja julkisia palveluja (Van Aerschot 2014, 175). 


\section{Omaisolettama lainsäädännössä}

Vaikka lainsäädännöllistä velvoitetta hoivaan ja elatukseen ei ole, lainsäädäntöön on kuitenkin kirjoitettu useaan kohtaan oletuksia omaisten roolista. Monesti sosiaali- ja terveydenhuollon lainsäädännöstä onkin luettavissa eränlainen toiminnallis-taloudellinen lojaalisuusolettama. Lainsädäntö on ristiriitainen. Omaisten oletetaan auttavan, vaikka vastaavaa velvollisuutta ei lainsäädännössä ole (Kalliomaa-Puha 2007, 24).

Suomessa on esimerkiksi käytössä kotitalousvähennys hoivapalveluiden ostamiseen, eikä pelkästään omalle perheelle, vaan myös omille tai puolison vanhemmille tai isovanhemmille ostetut palvelut saa vähentää tuloverotuksessa (tuloverolaki 1535/1992, 127ac §). Koko omaishoidon tuen järjestelmä rakentuu sille oletukselle, että löytyy halukkaita omaisia pitämään huolta vanhasta, vammaisesta tai sairaasta ihmisestä. Myös muuta rahallista kannustetta hoivan järjestämiseen, kuten Kelan maksamaa eläkkettä saavan hoitotukea, voidaan tarkastella tästä näkökulmasta. Usein rahan käyttäminen hoivan tai apuvälineiden ostoon vaatii nimittäin omaisten apua. Palvelusetelilain perusteluissa nimenomaisesti vedotaan perheisiin toteamalla, että palveluseteli on mahdollinen huonokuntoisillekin asiakkaille silloin, kun lähiomainen voi valita tämän puolesta (HE 20/2009,16). Perheet käsitetään vanhusten hoivan voimavaraksi, ja tukemalla perheiden hoivaa halutaan varmistaa informaalin hoivan jatkuvuus. Monissa maissa omaisten hoivaa tuetaan myös taloudellisesti. Tukea voidaan maksaa hoitajalle, kuten Ruotsissa, Norjassa, Islannissa, Unkarissa ja Isossa-Britanniassa tehdään, tai sitten hoidettavalle, kuten Hollannissa, Italiassa, Ranskassa tai Saksassa. Esimerkiksi Espanjassa, Italiassa ja Ranskassa on käytössä hoivaajan tai hoivantarvitsijan verotukseen liittyviä tuen muotoja. (Anttonen \& Sointu 2006, 93.) Suomessa on käytössä kaikki kolme keinoa: omaishoidon tuki, eläkettä saavan hoitotuki ja kotitalousvähennys, kuten edellä kuvattiin.

Tutkimukset antavat viitteitä siitä, että omaisolettama toimii myös palveluohjauksessa silloin, kun palvelun tarvetta harkitaan. Ruotsalaisen tutkimuksen mukaan palveluja saavat helpommin yksinäiset - ja vanhuksista ne, joilla ei ole tyttäriä - joiden siis oletetaan olevan valmiita ottamaan hoivavastuu. Omaisolettamassa on siis myös sukupuolioletus (Johansson 1993, 19, ks. myös Waerness 1990, 113).

Omaiset näkyvät vanhuspalvelulaissa ja uudessa sosiaalihuoltolaissa aiempaa enemmän. Vanhuspalvelulain 15 §:ssä vanhuksen palvelutarve selvitetään "tarvittaessa hänen omaisensa [ja] läheisensä"kanssa. Sosiaalihuoltolain muotoilussa omaiset otetaan hieman velvoittavammin mukaan: asiakkaan läheisverkosto kartoitetaan palvelutarvetta arvioitaessa ( $43 \S$ ). Lakia perusteleva hallituksen esitys toteaa läheisverkoston tarkoittavan kaikkia henkilöitä, jotka asiakas kokee itselleen läheiseksi. Varsinaisten perheenjäsenten lisäksi läheinen voi lain mukaan olla myös ystävä tai jopa järjestön ja muun kolmannen sektorin toimija, jolla on tärkeä rooli asiakkaan elämässä. Perusteluissa todetaan, että verkoston kartoittaminen on ollut olennainen osa vanhankin lain aikaan tehtyä perussosiaalityötä. Säännöksen ottamisella lakiin on haluttu tehdä näkyväksi läheisten antama tuki ja muistuttaa myös omaisten oikeudesta saada tarvittaessa tukea ja apua. (HE 164/2014.) Omaisia ei kuitenkaan oteta mukaan, jos itsestään määräämään kykenevä aikuinen ei sitä tahdo. Sosiaalihuoltolain 43 § ei oikeuta kartoittamaan läheisten osallistumista ilman asiakkaan suostumusta lukuun ottamatta kahta poikkeusta: tieto olisi tarpeen lapsen edun vuoksi tai tieto olisi välttämätön palvelutarpeen selvittämiseksi, kun henkilö on ilmeisen kykenemätön vastaamaan omasta huolenpidostaan, terveydestään ja turvallisuudestaan. Tällainen tilanne voi olla esimerkiksi muistisairaan vanhuksen kohdalla. 
Läheisverkoston kartoitus voidaan ymmärtää realismina: on viisasta kartoittaa, mitä vanhukselle on jo tarjolla ja miten arkea kannattaa lähteä tukemaan, etteivät omaiset ja julkinen tarjoa samaa asiaa. Mutta tämä asia voidaan ymmärtää myös perheiden vastuun kasvattamisena. Lain perusteluiden mukaan tavoite on kuitenkin ennen muuta tukea omaisia ja tuoda esiin heidän tekemäänsä työtä (HE 164/2014). Sosiaalihuoltolaissa velvoitetaan selvittämään myös omaisten ja läheisten mahdollinen tuen tarve. Lain 11 §:n mukaan "Sosiaalipalveluja on järjestettävä: --- 10) tuen tarpeessa olevien henkilöiden omaisten ja läheisten tukemiseksi." Kunta voi myös järjestää hoitavalle omaiselle vapaata, vaikka tämä ei olisikaan virallinen omaishoitaja (27b §).

Perheen tosiasiallinen vastuu voi näkyä myös asiakasmaksujen kautta. Parisuhteessa elävän vanhuksen laitoshoitomaksut määrätään parisuhteen muodosta riippumatta parin yhteenlaskettujen kuukausitulojen perusteella (asiakasmaksulaki 734/1992; Kangas 2014, 234-238). Mikäli perheelle tuloista jätettävä suojaosuus $(57,5 \%$ yhteenlasketuista tuloista) ei riitä perheen menoihin, tarvitaan kunnan työntekijöiden myönteistä tulkintaa. Asiakasmaksulain mukaan kunnan tulisi pienentää maksuja tai olla ottamatta niitä lainkaan, jos maksut vaarantavat henkilön tai perheen toimeentulon (11 §). Jossain kunnissa puolison ahdinko osataan ottaa huomioon (Kangas 2014, 235). Kun kerätään veroja, perusteena on yksilö ja hänen tulonsa. Perhe ei vaikuta veroihin. Mutta vanhustenhuollossa perhe onkin se tulonsaajayksikkö, jonka tulojen perusteella palvelumaksut määritellään.

Vaikka omaisolettama näkyy yhtäällä, ajatus omaisten hoivaan osallistumisesta ei ole kirjattu lainsäädäntöön johdonmukaisesti. Työlainsäädäntö ei tue juuri muuta kuin pienten lasten hoivan yhdistämistä ansiotyöhön. Vanhusten hoivaa ei ole käsitetty samalla lailla sitovaksi tai perheen tehtäväksi kuin pienten lasten hoiva. Hoivan luonteeseen kuuluu epävarmuus ja on ymmärrettävää, ettei hoiva ole yhdistettävissä kaikkiin työtehtäviin. Mutta jos haluamme työikäisten osallistuvan hoivaan, työn ja hoivan yhdistämisen keinojen kehittäminen on tärkeää. (Kauppinen \& SilfverKuhalampi 2015; ks. työikäisistä lasten omaishoitajista ja työelämän joustoista KalliomaaPuha \& Tillman 2016.) Työelämässä ei siis ole omaisolettamaa.

Omaisolettama toimii myös toiseen suuntaan: kun omaisilla ei ole mitään virallista asemaa - kun kysymys on vain oletuksesta - omaisilla ei usein ole juridista mandaattia hoitaa vanhuksen asioita. Tämä voi tarkoittaa esimerkiksi sitä, ettei virallinenkaan omaishoitaja saa tietoa hoidettavansa asioista ilman valtuutusta. Sosiaalihuollon asiakaslaissa ja potilaslaissa on varauduttu äärimmäisiin tilanteisiin. Mikäli vanhus ei itse kykene kertomaan tahtoaan, sosiaali- ja terveydenhuollon henkilöstön tulee selvittää vanhuksen oletettu tai tiedossa oleva tahto kuulemalla hänen laillista edustajaansa, omaista tai muuta läheistä. ${ }^{3}$ Arkisemmissa tilanteissa omainen ei saa tietoja ilman vanhuksen lupaa. Jotta omainen voi toimia vanhuksen puolesta, täytyy osata ennakoida ja tehdä valtuutuksia esimerkiksi terveydenhuoltoon, Kelaan, sopia yhteisistä pankkitileistä, kirjoittaa edunvalvontavaltuutus tai lopulta turvautua edunvalvontaan, viimekätiseen varajärjestelmään ihmisen oikeudellisen toimintakyvyn varalta. ${ }^{4}$

\footnotetext{
3 Omaisella tarkoitetaan lähinnä aviopuolisoa, lapsia, vanhempia ja sisaruksia. Muu läheinen voi olla esimerkiksi avopuoliso tai läheinen ystävä (potilaslaki $6 \S$, asiakaslaki 9 §, HE 137/1999). Ongelmia voi tulla silloin, kun omaiset ovat eri mieltä siitä, mitä vanhus olisi itse toivonut ja mikä tälle olisi parasta. Tällöin itse etukäteen tehty hoivatahto (hoitotestamentti) olisi avuksi. Malleja hoivatahtoon löytyy mm. THL:n, Muistiasiantuntijoiden, Muisti-liiton ja Exitus ry:n nettisivuilta. Ks. oikeudellisesta varautumisesta vanhuuteen yleisesti Mäki-PetäjäLeinonen 2013.

4 Ks. edunvalvonnasta ja edunvalvontavaltuutuksesta lähemmin laki holhoustoimesta 442/1999, laki edunvalvontavaltuutuksesta 648/2007 sekä Tornberg 2014 ja Mäki-Petäjä-Leinonen 2013.
} 
Palveluihin pääsyn monimutkaisuus edellyttää omaisten apua

Monissa kohdin sosiaalihuollon-, terveydenhuollon- ja toimeentuloturvan järjestelmä on niin monimutkainen, että heikkokuntoinen ihminen ei selviä yksin. Asiakkaan pitää päästä erilaisten kynnysten yli, suorittaa "kynnystehtäviä" palveluja saadakseen. Apua tarvitaan sopivan hoivan etsimiseen, hakemusten täyttämiseen, hoivan koordinointiin ja valintojen tekemiseen. Apua ja tukea tarvitaan tietysti sitä enemmän mitä huonompikuntoisemmasta vanhuksesta on kysymys. Apu voi olla julkisen vallan järjestämää tai se jää omaisten tehtäväksi. Tarvitaan palveluohjausta, laadun varmistusta ja jatkuvuudesta huolehtimista.(Valokivi 2008; Topo 2009; Häikiö ym. 2011; Lehto \& Tynkkynen 2013; Perttola 2015; KuusinenJames 2016.) Sosiaalihuoltolaki (42 §) pyrkii vastaamaan tähän velvoittamalla nimeämään vanhukselle omatyöntekijän, jonka tehtävänä on huolehtia yhteistyön järjestämisestä eri viranomaisten kesken ja tarpeisiin vastaavan palvelupaketin luomisesta ja ylläpitämisestä. Nähtäväksi jää, miten sosiaalihuoltolain säännökset omatyöntekijästä pystyvät vastaamaan tähän tarpeeseen.

Kasvava määrä yksityisiä palveluntarjoajia ja kuluttajan rooli hämärtää yksityisten ja julkisten palvelujen rajaa. Tällä on merkitystä oikeusturvan kannalta. Vanhus voi esimerkiksi olla kunnan ostopalveluasiakkaana yksityisessä palvelutalossa. Kunta maksaa asumisen ja vanhus ostaa omalla rahalla lisäpalveluja ja kuuluu niiden osalta kuluttajansuojan piiriin. Asumispäätöksestä pitäisi sen sijaan osata reklamoida kuntaan. Naapurihuoneessa voi sen sijaan asua vanhus, joka maksaa myös asumisensa itse ja asioi siksi pelkästään palvelutaloyrittäjän kanssa. Ei siis ole ihme, jos on vaikea tietää, kuka viime kädessä vastaa palvelun laadusta ja minne laatupuutteista pitäisi ilmoittaa. Kuluttajariitalautakuntaan on valitettu julkisista palveluista, vaikka se ei niitä saa käsitellä (KRIL 13.9.2007). Viime aikoina ollaankin oltu huolestuneita siitä, osaavatko asiakkaat tunnistaa eri tuottajat ja toimia oikein (Arajärvi 2010; Oikeusministeriö 2011; Huhtanen 2012). Sote-suunnitelmissa tämä aiotaan ratkaista asettamalla kaikki tuottajat samalle viivalle. Vielä on ratkaisematta, miten yksityisyys tai julkisuus vaikuttaa muutoksenhakuun, josta lähemmin alla.

Esimerkiksi palveluseteli tarkoittaa, että vanhus itse tai hänen omaisensa tekee sitä valintatyötä, minkä aiemmin olisi tehnyt kunta. Kuluttajan valinnanvapaus tarkoittaa myös uutta sosiaalista riskiä eli riskiä tehdä huonoja valintoja (Roostgaad 2011, 67; KalliomaaPuha 2014). Isoissa asioissa tehdyt väärät valinnat tulevat yhteiskunnallekin kalliiksi tekipä valinnan vanhus itse tai hänen omaisensa. Paradoksaalisesti valinnanmahdollisuuksia on palvelusetelin avulla avattu sosiaalipalveluissa ensisijaisesti vajaakuntoisille ja paljon apua tarvitseville ikäihmisille, joita yleensä pidetään heikkoina valitsijoina ja kuluttajina. (Kuusinen-James \& Seppänen 2013, 318, ks. myös Laatu ym. 2010.) Kuluttajana hoivamarkkinoilla ei näin toimikaan palvelusetelin saanut avuntarvitsija, vaan hänen omaisensa valtakirjakuluttajana tai vähintään kanssakuluttajana (Mold 2010). Kun valinnanvapautta lisätään, on hyvä kysyä, kenen valinnanvapautta ollaan lisäämässä. Ei ainakaan heikkokuntoisen vanhuksen tai muistisairaan ihmisen. Jos palvelut tarjotaan heille esimerkiksi palvelusetelillä (tai uusien sote-suunnitelmien mukaan asiakassetelillä tai henkilökohtaisella budjetilla, ks. alueuudistus-nettisivut), on selvää, että jonkun - usein omaisen - täytyy valita heidän puolestaan. Valinnanvapauden korostaminen tarkoittaa tosiasiassa omaisten vastuun kasvattamista.

Silloin kun palveluita on paljon, omaista tarvitaan yksinkertaisesti huolehtimaan palvelujen kokonaisuudesta. Kuten kuviosta 1 näkyy, palvelujen määrä voi olla melkoinen. Palveluita tuottavat kunta, järjestöt ja yritykset. Vanhuspalveluja myös usein kehitetään määrä- 


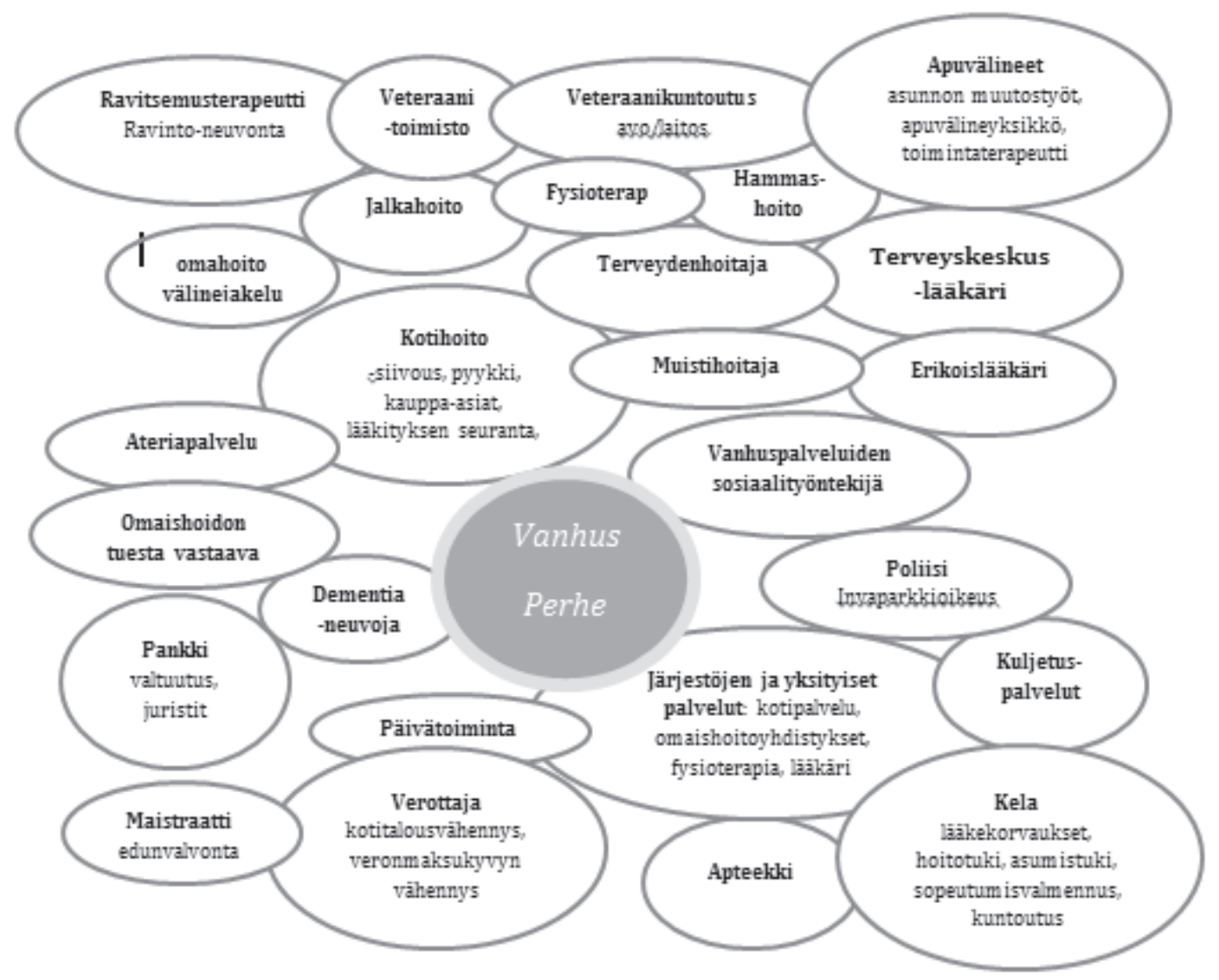

Kuvio 1. Omaishoitoperheen palvelut. (Saarenheimo E̊ Pietilä 2006)

aikaisissa hankkeissa, jotka myös lisäävät toimijoita. Ei ole tavatonta, että saman vanhuksen luona voi käydä kotipalveluja tarjoamassa henkilöitä näistä kaikista tahoista. Ja kun yhä huonokuntoisempien vanhusten hoiva järjestetään kotona, myös tarvittavien palveluiden kirjo on kasvanut. (Topo 2009, 233-234.) Kaikilla ammattilaisilla voi olla oma käsityksensä siitä, mikä olisi vanhukselle parhaaksi (Saarenheimo \& Pietilä 2006, 78). Kuvio 1 kuvaa erään omaishoitoperheen palvelut Marja Saarenheimon ja Minna Pietilän tutkimuksen mukaan kymmenen vuotta sitten. Painotus avohuoltoon ei ole tuosta ajasta vähentynyt, joten kuvio kertoo edelleen avohuoltoa saavien vanhusten tilanteesta. Kuvio osoittaa mainiosti, millaisia organisaattorin kykyjä ihmisiltä edellytetään, jotta tällainen järjestely saadaan toimimaan.

Jälkikäteinen oikeusturva ja omaisolettama

Monimutkaisuuden ongelma on tunnistettavissa myös jälkikäteisessä oikeusturvassa. Jos vanhus ei saa sitä palvelua tai etuutta, joka hänelle kuuluisi, hänellä on aina mahdollisuus hakea muutosta. Kaikista hallintopäätöksistä voi valittaa eli päätöksistä, joilla joko myönnetään tai evätään palvelu tai etuus. Vanhuspalveluissa - kuten sosiaali- ja terveydenhuollon palveluissa yleensäkin - ongelmana on se, ettei varsi- 
naisessa hoivatyössä tehdä valituskelpoisia päätöksiä. Mutta huonosta laadusta, epäkohteliaisuudesta tai virheestä palvelussa voi tehdä muistutuksen tai kantelun. ${ }^{5}$ Vaikka kantelu tai muistutus ei voi muuttaa päätöstä, kantelu tai muistutus voi muuttaa viranomaisten käytäntöjä. Jälleen voimme todeta, että järjestelmän tasolla on tarjolla välineitä käsitellä ongelmaa, huonoa kohtelua tai virheitä. Mutta mitä muistutus, kantelu tai valitus edellyttävät?

Ensinnäkin ne edellyttävät sitä, että henkilö ymmärtää päätöksen ja muutoksenhakuohjeet. Virkakieli on moneen kertaan todettu vaikeaksi ymmärtää ${ }^{6}$. Moni palvelujen tarpeessa oleva vanhus tarvitsee apua päätöksen tulkitsemisessa, ei vähiten muistisairauksista kärsivät, vammaiset tai maahanmuuttajat, joilla on kieliongelmia. Kun prosessi on lähes täysin kirjallinen, ei muutoksenhaku tosiasiallisesti ole huonosti suomea osaavan vanhuksen ulottuvilla.

Toiseksi tarvitaan tietoa: Mitkä ovat oikeuteni? Kannattaako valittaa? Mihin valittaa ja miten? Toisin sanoen tarvitaan oikeudellista osaamista. Hallinnollisissa päätöksissä on aina mukana muutoksenhakuosoitus, jossa kerrotaan valitustie ja valitusaika. Silti oikean instanssin ja menettelyn hahmottaminen voi olla vaikeaa. Ensinnäkin valituspolkuja on kolme. Kelan etuuksista - toimeentulotukea lukuun ottamatta - valitetaan ensiasteessa muutoksenhakulautakuntiin ja niistä vakuutusoikeuteen. Kunnallisista päätöksistä valitetaan ensin kunnalliselle lautakunnalle, jonka jälkeen asian voi viedä hallinto-oikeuteen. Jossain asioissa valitustie on avoinna korkeimpaan hallintooikeuteen asti. Markkinoilla olevien palvelujen kiistoja ratkotaan tavallisissa käräjäoikeuksissa tai kuluttajariitalautakunnassa. Myös kanteluille on eri polkuja. Kantelun voi tehdä ylim-

5 Ks. jälkikäteisestä oikeusturvasta Tuori \& Kotkas 2016, 425; Valkonen 2017; Koulu 2017.

6 Tiililä 2007. Hyvä virkakieli on jatkuvan kehityksen tarpeessa, ks. Kotimaisten kielten keskuksen Hyvää virkakieltä kolumnit: https://www.kotus.fi/nyt/kolumnit/hyvaa_virkakielta . mille lainvalvojille eli Eduskunnan oikeusasiamiehelle tai Oikeuskanslerille tai valvoville viranomaisille kuten aluehallintovirastoihin tai Valviraan ${ }^{7}$. Terveydenhuollossa jälkikäteistä oikeusturvaa tarjoaa myös potilasvahinkolautakunta, josta voi saada vahingonkorvausta. Muistutus tehdään palveluntarjoajalle suoraan. Kotimaisten instituutioiden lisäksi tarjolla ovat vielä kansainväliset elimet, kuten esimerkiksi Euroopan ihmisoikeustuomioistuin.

Lisäksi valittamiseen, kantelemiseen ja muistuttamiseen tarvitaan rohkeutta. Tämä vaatimus vähentää näiden oikeusturvakeinojen toimivuutta niin yksilön kuin järjestelmän toimivuuden kehittymisen kannalta. Moni ei uskalla valittaa kaltoin kohtelevasta hoitajasta tai huonosta palvelusta tai edes suoranaisista virheistä, koska pelkää, ettei saa hyvää palvelua enää muistutuksen teon jälkeen (KuusinenJames \& Seppänen 2013, 324-325). Silloin tieto huonosti toimivista palveluista tai suoranaista epäkohdista ei välity myöskään palvelujen kehittäjille.

Oikeusturva edellyttää usein myös vaurautta - pitää olla varaa odottaa asian ratkeamista ja järjestää palvelu ensin itse, varautua korvaamaan mahdollisia vastapuolen kuluja, jos jutun häviää, tai varaa palkata itselle oikeudellista apua. Vaikka hallinnolliset muutoksenhakureitit on suunniteltu siten, ettei avustaja olisi välttämätön, lienee selvää, että kaikki eivät niistä yksin suoriudu (Koulu 2017; Valkonen 2017). Jälleen punnitaan paitsi omat, myös omaisten, kyvyt, jaksaminen ja osaaminen. Varakkailla vanhuksilla tai heidän omaisillaan on mahdollisuus ostaa apua.

USA:ssa ja Kanadassa onkin syntynyt vanhusten asioiden hoitamiseen ihan oma asianajajakunta, elder law attorneys, joilla on oma

\footnotetext{
7 Sote-uudistuksessa suunnitellaan myös valvontaviranomaisten, Valviran ja aluehallintovirastojen, uudistusta. On mahdollista, että luodaan valtakunnallinen valvontaelin. Ks. lähemmin Valtion lupa, ohjaus ja valvontavirastoa valmisteleva ryhmä.
} 
asianajajatutkintonsa, koulutusta ja erityinen asianajajavälitys ${ }^{8}$. Siellä nämä "vanhusasianajajat" keskittyvät paljon kuluttajaoikeuteen, koska vanhuspalvelut ovat pitkälti yksityisiä. Ainakin toistaiseksi meillä on ajateltu, että apua tarvitseva ihminen ei ole julkisen vallan vastapuoli, joka tarvitsisi asianajajaa. Ruotsissa - jossa järjestelmä on kuitenkin lähellä meidän järjestelmäämme - on tosin ehdotettu kansallista vanhusasiamiestä valvomaan vanhusten etuja (Mattson 2013). ${ }^{9}$

Voidaan myös pohtia muutoksenhaun mielekkyyttä ajan kulumisen näkökulmasta. Muutosprosessit vievät aikaa: sosiaaliturvan muutoksenhakulautakunnassa valituksen käsittely vei keskimäärin seitsemän kuukautta, hallinto-oikeuksissa lähes puolet asioista ratkaistaan alle kuudessa kuukaudessa, 76 prosenttia alle vuodessa, eduskunnan oikeusasiamiehellä kantelu saadaan keskimäärin käsitellyksi hieman yli kolmessa kuukaudessa (Hallintotuomioistuinten toimintakertomus 2014; Sosiaaliturvan muutoksenhakulautakunnan toimintakertomus 2015; Eduskunnan oikeusasiamiehen toimintakertomus 2015). Sairaille ihmisille monen kuukauden odottaminen voi olla mahdotonta. Vaikka odotusajat ovat lyhentyneet, muutamakin kuukausi ruokarahan odottelua, lääkkeiden oston viivästymistä tai hoitoon pääsyn lykkääntymistä voi olla liikaa. Tässä hoivapalveluiden erityisyys tulee näkyväksi: tuomioistuimet eivät voi hoitaa ihmistä eikä oikea ratkaisu enää auta,

8 Ks. esim. National Academy of Elder Law Attorneys tai National Elder Law Section of the Canadian Bar Association.

9 Suomessa ei ole valtakunnallista vanhusasiamiestä eikä vanhusasiamiehistä säädetä lainsäädännössä kuten esimerkiksi sosiaaliasiamiehistä säädetään. Joissakin kunnissa on nimetty erityinen vanhusasiamies neuvomaan ja auttamaan vanhuspalveluiden järjestymisessä (esim. Tampereella ja Sipoossa) ja muutamiin kuntiin on ehdotettu vanhusasiamiehen tehtävän perustamista (esim. Helsinkiin ja Turkuun). Hallintolain ja asiakaslain mukaan kaikkien kunnan työntekijöiden tulisi neuvoa ja opastaa asiakkaita, myös sosiaali- ja potilasasiamiehillä on sellainen rooli. kun akuutti tarve on pahentunut tai seuraukset ovat jo peruuttamattomia. Varakas vanhus tai omainen voi ostaa palveluita odotusajalle. Vanhushoivapalveluissa, jos missä, kannattaisikin panostaa etukäteiseen oikeusturvaan eli prosessien hiomiseen siten, että asiat menisivät kerralla oikein ja että asiakkaista myös tuntuisi siltä.

\section{Johtopäätökset: omaisköyhyys ja omaisolettama}

Edellä on osoitettu, että vanhuksen oikeus hoivaan on taattu lainsäädännössä - viimekädessä perustuslaissa. Koska yhtäältä tarve hoivaan on joskus vaikea osoittaa ja toisaalta tarpeeseen vastaavasta hoivamuodosta voidaan olla montaa mieltä, ei edes subjektiivinen oikeus ole aina helposti todennettavissa. Vaikka oikeus hoivaan onkin, sitä voidaan tarjota tavalla, joka ei tyydytä vanhusta tai tavalla, jolla vanhus ei yksin selviä. Sopivien palvelujen löytämisessä, palveluiden hakemisessa, palvelujen koordinoinnissa ja lopulta mahdollisten virheiden korjaamisessa on kynnystehtäviä, joissa useimmat vanhukset saattavat tarvita apua. Lainsäädäntö olettaa - joskus auki kirjoitettuna, kuten esimerkiksi omaishoidossa tai palvelusetelilain esitöissä - että omaiset auttavat vanhusta. Joskus oletus omaisten avusta on seurausta järjestelmän monimutkaisuudesta ja kynnystehtävien vaikeudesta. Valinnanvapauden lisääntyminen ja kuluttajuus ovat omiaan lisäämään tätä monimutkaisuutta ja sitä kautta omaisten vastuuta. Myös esimerkiksi ympärivuorokautisen hoivan leikkaukset lisäävät omaisten vastuuta (Jylhä 2014, ks. myös esim. Vilkko ym. 2014 ja Colombo ym. 2011).

Ovatko lainsäädännön oletukset omaisista sitten ongelma? Eikö ole vain hyvä, että omaiset ovat mukana auttamassa, kun apua tarvitaan? Kyllä. On myös hienoa, että lainsäädäntö enenevästi tunnistaa ja tunnustaa omaisten tekemää työtä. Omaisten, muidenkin kuin virallisten omaishoitajien, palvelutarpeita on huo- 
mioitu esimerkiksi sosiaalihuoltolaissa. Emme toisaalta vielä tiedä, miten nämä sosiaalihuoltolain melko uudet normit on otettu käyttöön. Omaisten mahdollisuus vapaisiin ja muihin palveluihin on kirjoitettu sosiaalihuoltolakiin tavalla, joka ei synnytä subjektiivista oikeutta ja jättää paljon harkintavaltaa kunnille. Jää nähtäväksi, miten omaisten tukeminen otetaan huomioon uusissa maakunnissa sote-ratkaisujen jälkeen.

Omaisolettama ei kuitenkaan ole ongelmaton. Olettama on ristiriitainen. Lainsäädäntömme paitsi yhtäältä tukee omaisten osallistumista erilaisin kannustimin, kuten kotitalousvähennyksellä, omaishoidon palkkiolla sekä muilla omaisten tukipalveluilla, toisaalta pitkälti jättää vanhustenhuollon huomiotta esimerkiksi ansiotyön ja vanhustenhoivan yhteensovittamisessa. Omaisolettama myös haastaa vanhusten yhdenvertaisuutta. Omaisen tehokas apu edellyttää usein oikeudellista ennakointia, kuten erilaisten valtuutusten tekemistä. Kaikilla ei tällaista osaamista ole eikä tällainen ennakointi siksi onnistu. Omaisen ja vanhuksen sosioekonominen tausta vaikuttaa siihen, miten oikeus hoivaan ja hoivan tarpeen arviointiin toteutuu.

Ja entä jos omaisia ei ole? Tai omaiset eivät kykene auttamaan esimerkiksi oman terveydentilansa vuoksi? Tai omaiset eivät halua auttaa? Tai he valitsevatkin oman mielensä mukaan, ei avuntarvitsijan mielen mukaan, tai jopa avuntarvitsijan etujen vastaisesti?

\section{Kirjallisuus}

Alueuudistus. Haettu 20.9.2017 osoitteesta: http:// alueuudistus.fi/soteuudistus/asiakkaan-valinnanvapaus

Anttonen, A. \& Sointu, L. (2006). Hoivapolitiikka muutoksessa. Julkinen vastuu pienten lasten ja ikääntyneiden hoivasta 12:ssa Euroopan maassa. Hyvinvointivaltion rajat -hanke. Helsinki: Stakes.

Arajärvi, P. (2010). Avuton julkisen ja yksityisen muutoksessa. Teoksessa Pajukoski, M. (toim.),
Omaiset ovat tärkeä resurssi siinä missä oma tietotaito, varallisuus tai toimintakyky (Van Aerschot 2014, 176-177). On vaikeaa selvitä avuntarvitsijana yksin. Yksinäisyys on iso riski paitsi palveluiden piiriin pääsyssä, myös niiden käytössä, johtuipa yksinäisyys sitten omaisten puutteesta tai siitä, etteivät omat omaiset ole halukkaita auttamaan tai riittävän taitavia toimijoita sosiaali- ja terveysmarkkinoilla."Omaisköyhyys"Teppo Krögerin (2005) hoivaköyhyys termiä mukaillen on kasvava hoivaköyhyyden laji, ja sillä on vakavia vaikutuksia ihmisten palvelujen saatavuuteen ja hyvinvointiin. Kun lainsäädäntökin olettaa omaisten olevan tukemassa vanhusta, helposti unohtuu se, ettei kaikilla ole läheisiä tukenaan. Toisaalta suurin riski jäädä palvelujen ulkopuolelle voikin olla niillä vanhuksilla, joilla on omaisia - joiden oletetaan auttavan - mutta jotka eivät kuitenkaan halua tai osaa tai kykene auttamaan.

Pitää tunnustaa, että omaisten vastuuta lisäävät ratkaisut lisäävät myös joidenkin vanhusten riskiä jäädä ilman perustuslain heille takaamia oikeuksia. Mikäli otamme vanhusten oikeuden hoivaan vakavasti, tähän riskiin pitää varautua varaamalla riittävästi varoja heidän tukensa järjestämiseen.

\section{Yhteydenotto: \\ Laura Kalliomaa-Puha, OTT, apulaisprofessori \\ Yhteiskuntatieteiden tiedekunta, \\ Tampereen yliopisto \\ Sähköposti: laura.kalliomaa-puha@staff.uta.fi}

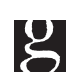

Pääseekö asiakas oikeuksiinsa? (s. 147-158). Sosiaali- ja terveydenhuollon ulkopuoliset tekijät -työryhmä, Raportti III. Helsinki: Terveyden ja hyvinvoinnin laitos.

Arajärvi, P. (2011). Johdatus sosiaalioikeuteen. Helsinki: Talentum.

Arajärvi, P. (2014). Vanhuspalvelulaki - mitä ja miksi? Teoksessa Mäki-Petäjä-Leinonen, A. \& Nieminen, L. (toim.), Vanbuus ja oikeus (s. 257282). Helsinki: Lakimiesliiton kustannus. 
Van Aerschot, L. (2014). Vanbusten hoiva ja eriarvoisuus, sosiaalisen ja taloudellisen taustan ybteys avun saamiseen ja palvelujen käyttöon. Tampere: Tampere University Press, Acta Universitatis Tamperensis : 1971. Haettu 29.10.2016 osoitteesta: http://urn.fi/URN:ISBN:978-951-44-9568-7

Asiakaslaki. Laki sosiaalihuollon asiakkaan asemasta ja oikeuksista 812/2000.

Avioliittolaki 234/1929.

Colombo, F., Llena-Nozal, A., Mercier J. \& Tjadens F. (2011). Help wanted? Providing and paying for long-term care. OECD. Haettu 24.4.2017 osoitteesta: http://www.oecd.org/els/health-systems/ help-wanted-9789264097759-en.htm

Eduskunnan oikeusasiamiehen kertomus vuodelta 2015. Haettu 27.10.2016 osoitteesta: http://www.oikeusasiamies.fi/Resource.phx/eoa/julkaisut/toimintakertomukset.htx

Hallintotuomioistuinten vuosikertomus 2014. Haettu 27.10.2016 osoitteesta: http://www.kho.fi/fi/index/julkaisut/hallintotuomioistuintenyhteisettoimintakertomukset.html

Hallintolaki 434/2004.

Hallintolainkäyttölaki 586/1996.

HE 309/1993 Hallituksen esitys Eduskunnalle perustuslakien perusoikeussääntöjen muuttamisesta.

HE 137/1999 Hallituksen esitys Eduskunnalle laeiksi sosiaalihuollon asiakkaan asemasta ja oikeuksista sekä sosiaalihuoltolain muuttamisesta ja eräiksi niihin liittyviksi laeiksi.

HE 20/2009 Hallituksen esitys Eduskunnalle laeiksi sosiaali- ja terveydenhuollon palvelusetelistä sekä sosiaali- ja terveydenhuollon asiakasmaksuista annetun lain 12 §:n muuttamisesta.

HE 164/2014 Hallituksen esitys eduskunnalle sosiaalihuoltolaiksi ja eräiksi siihen liittyviksi laeiksi.

Hoffman, F. \& Rodrigues R. (2010). Informal Carers: Who Takes Care of Them? European Centre Policy Briefs April 2010. Haettu 24.4.2017 osoitteesta: http://www.euro.centre.org/ data/1274190382_99603.pdf_

Hoppania, H.K., Karsio O., Näre L., Olakivi A., Sointu L., Vaittinen T. \& Zechner M. (2016). Hoivan arvoiset. Vaiva ybteiskunnan ytimessä. Helsinki: Gaudeamus.

Huoltoapulaki 116/1956.

Häikiö, L., Van Aerschot, L. \& Anttonen, A. (2011). Vastuullinen ja valitseva kansalainen: vanhushoivapolitiikan uusi suunta. Yhteiskuntapolitiikka, 76(3), 239-250.
Hämeenlinnan lääninoikeus 3.9.1998 430/3.

Hämeenlinnan hallinto-oikeus 22.5.2002 02/0249/4 . Hämeenlinnan hallinto-oikeus 12.7.2004 04/0256/4. Johansson, S. (1993). A Revoluton of Free Choices - The Swedish Welfare State in Transition. Teoksessa Simonen, L. (toim.), Hyvinvointivaltion murros ja hoivan uudelleenorganisointi (s. 10-31). Sosiaali- ja terveysalan tutkimus- ja kehittämiskeskuksen raportteja 94. Helsinki: Stakes,

Juntunen, K. \& Salminen, A.K. (2014). Mikä omaishoitajia kuormittaa? Omaishoitajien jaksaminen ja tuen tarve COPE-indeksillä mitattuna. Teoksessa Tillman, P., Kalliomaa-Puha, L. \& Mikkola, H., (toim.), Rakas mutta raskas työ. Kelan omaishoitohankkeen ensimmäisiä tuloksia (s. 69-81). Työpapereita 69. Helsinki: Kelan tutkimus.

Jylhä M. (2014). Vanhuspalvelulain muutosten ihmettelyä. Gerontologia, 28(4), 266-268.

Kalliomaa-Puha, L. (2007). Vanhoille ja sairaille sopivaa? Omaishoitosopimus hoivan instrumenttina. Helsinki: Kelan tutkimusosasto, Tutkimuksia 90.

Kalliomaa-Puha, L. (2014). Slow-go ja no-go kuluttajat markkinoilla. Teoksessa Mäki-PetäjäLeinonen, A. \& Nieminen, L. (toim.), Vanbuus ja oikeus (s. 323-352). Helsinki: Lakimiesliiton kustannus.

Kalliomaa-Puha, L. \& Kangas, O. (2015). Yksityistä ja yhteistä varautumista. Vanhusten hoivan tulevaisuus. Helsinki: Kalevi Sorsa säätiö.

Kalliomaa-Puha, L \& Tillman,P. (2016). Äiti on aina äiti. Lasten omaishoitajien arjen haasteet. Teoksessa Haataja, A., Airio, I., Saarikallio-Torp, M. \& Valaste, M. (toim.), Laulu 573566 perheestä. Lapsiperheet ja perhepolitiikka 2000-luvulla (s. 322-355). Helsinki: Kelan tutkimus 2016.

Kangas, U. (2013). Perhe-ja jäämistöoikeuden perusteet. Helsinki: Alma Talent.

Kangas, U. (2014). Laitoshoitomaksun määrittämisen ongelmia. Teoksessa Mäki-Petäjä-Leinonen A. \& Nieminen, L. (toim.), Vanbuus ja oikeus (s. 221-256). Helsinki: Lakimiesliiton kustannus.

Karvonen-Kälkäjä, A. (2017). Oikeus vanhuspalveluihin ja viivästys palvelujen järjestämisessä. Teoksessa Nykänen, E., Kalliomaa-Puha., L. \& Mattila, Y. (toim.), Sosiaaliset oikeudet - näkökulmia perustaan ja toteutumiseen (s. 138-148). Helsinki: Terveyden- ja hyvinvoinnin laitos.

Kauppinen, K. \& Silfver-Kuhalampi, M. (2015). Työssäkäynti ja läheis- ja omaishoiva - työssä jak- 
samisen ja jatkamisen tukeminen. Sosiaalitieteiden laitoksen julkaisuja 2015:12. Helsinki: Unigrafia.

Kehusmaa, S. (2014). Hoidon menoja hillitsemässä. Heikkokuntoisten kotona asuvien ikäihmisten palvelujen käyttö, omaishoito ja kuntoutus. Helsinki: Kelan tutkimusosasto, Sosiaali- ja terveysturvan tutkimuksia 131.

KHO 22.9.2000 T 2366. Päihdehuolto - Yksityisesti hankitun palvelun korvaaminen.

KHO 2002:21. Erikoissairaanhoito - Yksityisesti hankitun hoidon korvaaminen - Maksusitoumus - Hallintoriita.

Kotkas, T. (2014). Suomalaiseläkeläisen oikeus rajat ylittävään terveydenhuoltoon Euroopan Unionissa. Teoksessa Mäki-Petäjä-Leinonen, A. \& Nieminen, L. (toim.), Vanhuus ja oikeus (s. 173196). Helsinki: Lakimiesliiton kustannus.

Koulu, R. (2017). Mainettaan paremmatko muutoksenhakulautakunnat? Teoksessa Nykänen E., Kalliomaa-Puha, L. \& Mattila, Y. (toim.) Sosiaaliset oikeudet - näkökulmia perustaan ja toteutumiseen (s. 180-196). Helsinki: Terveyden- ja hyvinvoinnin laitos.

KRIL 13.9.2007. Kuluttajariitalautakunta. Hammaslääkärin palvelut.Julkisen terveydenhuollon ostopalvelu.

Kröger, T. (2005). Hoivaköyhyys yksinhuoltajaperheissä: kenelle lastenhuolto-ongelmat kasautuvat? Teoksessa Takala, P. (toim.), Onko meillä malttia sijoittaa lapsiin? (s. 206-233). Helsinki: Kelan tutkimusosasto 2005.

Kuusinen-James, K. (2016). Setelipeliä. Tutkimus palveluseteliä säännöllisessä kotihoidossa käyttävien iäkkäiden henkilöiden valinnanvapaudesta. Helsinki: Helsingin yliopisto. Valtiotieteellisen tiedekunnan julkaisuja 32 .

Kuusinen-James, K. \& Seppänen, M. (2013). Ikääntyvät palvelusetelin käyttäjät valintatilanteessa: kuluttajia vai näennäiskuluttajia? Janus, 21(4), 314-329.

Köyhäinhoitolaki 145/1922.

Laatu, M., Salminen A.L., Kalliomaa-Puha, L. \& Autti-Rämö, I. (2010). "Setelillä kuntoon?" (s. 33-41). Kuntoutus 3.

Laki edunvalvontavaltuutuksesta 648/2007.

Laki holhoustoimesta 442/1999.

Lehto, J., Tynkkynen, L.K. (2013). Älykkäästi suunnitellut sosiaali- ja terveydenhuollon markkinat. Yhteiskuntapolitiikka, (78)6, 605-617.
Liikunta ja ikääntymien - liikkeellä voimaa vuosiin. Valtion liikuntaneuvoston julkaisuja 2013:5.

Lohiniva-Kerkelä, M. (2014). Iäkkään potilaan asema ja oikeudet terveyden- ja sairaanhoidossa. Teoksessa Mäki-Petäjä-Leinonen, A. \& Nieminen, L. (toim.) Vanhuus ja oikeus (s. 145-171). Helsinki: Lakimiesliiton kustannus.

Mattson, T. (2013). National Ombudsman for the Elderly: A solution for a more responsive welfare state? Retfard Årgang 36(3/142), 9-24.

Meagher, M. \& Szebehely, M. (toim.) (2013). Marketization in Nordic Eldercare - a research report on legislation, oversight, extent and consequences. Stockholm: Stockholm University.

Mikkelin lääninoikeus 5.2.1992 56. Päihdehuolto - hoitopalvelujen järjestäminen - maksusitoumus hoitomaksuun.

Mikkola, M. (2014). Ikäihmisten sosiaaliset ihmisoikeudet. Teoksessa Mäki-Petäjä-Leinonen, A. \& Nieminen, L. (toim.), Vanhuus ja oikeus (s. 1972). Helsinki: Lakimiesliiton kustannus.

Mold, A. (2010). Patient groups and the Construction of the Patient-Consumer in Britain: Historical Overview. Journal of Social Policy, 39(4), 505-521.

Mäki-Petäjä-Leinonen, A. (2013). Ikääntymisen ennakointi. Vanhuuteen varautumisen keinot. Helsinki: Lakimiesliiton kustannus.

National Academy of Elder Law Attorneys. Haettu 27.10.2016 osoitteesta: www.naela.org

National Elder Law Section of the Canadian Bar Association. Haettu 27.10.2016 osoitteesta: http://www.cba.org/Sections/Elder-Law

Oikeusministeriö (2011). Asiakkaansuojan kehittäminen julkisissa hyvinvointipalveluissa. Mietintöjä ja lausuntoja 13/2011. Helsinki: Oikeusministeriö.

Peiponen, A. (2010). Helsingin vanhuspalvelut. Esitelmä Suomen sosiaalioikeudellisen seuran keskustelutilaisuudessa 11.3.2010. Haettu 27.10.2016 osoitteesta: http://ssos.nettisivu.org/seuran-tilaisuudet/

Perttola, L. (2015). Tiedonsaanti vanhuspalvelujen myöntämisperusteista. Oikeus, 3, 238-258.

Poikonen, H. (2017). Perusoikeussääntelyn vaikutuksista oikeuteen saada päihdepalveluja. Teoksessa Nykänen E., Kalliomaa-Puha, L. \& Mattila, Y. (toim.), Sosiaaliset oikeudet - näkökulmia perustaan ja toteutumiseen (s. 114-137). Helsinki: Terveyden- ja hyvinvoinnin laitos. 
Potilaslaki: Laki potilaan asemasta ja oikeuksista 785/1992.

Päihdehuoltolaki 41/1986.

Pöllänen, P. (2013). Hoivan rajat. Venäläiset maahanmuuttajanaiset ja ylirajainen perhehoiva. Väestötutkimuksen julkaisusarja D 57. Helsinki: Väestöliitto.

Rajavaara, M. (2014). Ammattilaisen harkintavalta sosiaaliturvan edellytyksenä ja riskinä. Teoksessa Kalliomaa-Puha, L., Kotkas, T. \& Rajavaara, M. (toim.), Harkittua - avauksia sosiaaliturvan harkintavallan tutkimukseen (s. 136-155). Helsinki: Kelan tutkimus.

Rintala, T. (2003). Vanhuskuvat ja vanhustenhuollon muotoutuminen 1850-luvulta 1900-luvulle. Sosiaali- ja terveysalan tutkimus ja kehittämiskeskus, Tutkimuksia 132. Helsinki: Stakes.

Roostgard, T. (2011). Care as you like it: the construction of a consumer approach in home care in Denmark. Nordic Journal of Social Research, 2, 54-69.

Saarenheimo,M. \& Pietilä,M. (2006). Omaishoito ja palvelujärjestelmä. Teoksessa Eloniemi-Sulkava, U., Saarenheimo, M., Laakkonen, M-L., Pietilä, M., Savikko, N. \& Pitkälä, K, (toim.), Omaishoito yhteistyönä. Iäkkäiden dementiaperheiden tukimallin vaikuttavuus. (s. 68-80). Geriatrisen kuntoutuksen kehittämishanke, tutkimusraportti 14 . Helsinki: Vanhustyön keskusliitto.

Sointu, L. (2016). Hoiva subteessa. Tutkimus puolisoaan hoivaavien arjesta. Tampere Acta Universitatis Tamperensis 2195. Tampere: University Press.

Sosiaalihuoltolaki 1301/2014.

Sosiaaliturvan muntoksenhakulautakunnan toimintakertomus 2015. Haettu 27.10.2016 osoitteesta: http://www.sosiaaliturvanmuutoksenhakulautakunta.fi/index.php?item $=125$

Suomen perustuslaki 731/1999.

Theobald, H. (2011). Long-term Care Insurance in Germany: Assessments, benefits, care arrangements and funding. Arbetsrapport 2011:13. Stockholm: Institutet för Framtidsstudier.

Terveydenhuoltolaki 1326/2010.

Tiililä, U. (2007). Tekstit viraston työssä. Tutkimus etuuspäätösten kielestä ja konteksteista. Helsinki: Helsingin yliopisto. Haettu 27.10.2016 osoitteesta: http://www.ethesis.helsinki.fi
Timonen V. (2014). Elderly care in Ireland. Esitelmä Kalevi Sorsa Säätiön ja Finanssialan keskusliiton järjestämässä seminaarissa Eduskunnan pikkuparlamentissa 6.10.2014. Haettu 27.10.2016 osoitteesta: https://www.youtube.com/watch?$\mathrm{v}=\mathrm{PR} 9$ oianTbVM

Topo, P. (2009). Asiakkaana iäkkäille suunnatuissa palveluissa. Teoksessa Koivusalo, M., Ollila, E. \& Alanko, A. (toim.), Kansalaisesta kuluttajaksi. Markkinat ja muutos terveydenbuollossa (s. 227247). Helsinki: Gaudeamus.

Tornberg J. (2014). Ikääntyminen ja edunvalvonta kiinteistön vaihdannassa - käytännön ongelmatilanteita kirjaamisasioissa. Teoksessa MäkiPetäjä-Leinonen, A. \& Nieminen, L. (toim.), Vanhuus ja oikeus (s. 431-460). Helsinki: Lakimiesliiton kustannus.

Tuori, K. (2005). Sosiaalioikeus. Helsinki: WSOY.

Tuori, K. \& Kotkas, T. (2016). Sosiaalioikeus. Helsinki: WSOYPro.

Turun hallinto-oikeus 25.3.2014 14/0173/2. Sosiaalipalvelu - palveluasuminen - perhehoito - vanhuspalvelulaki.

Turun hallinto-oikeus 25.1.2012 01751/11/6110. Omaishoidon tuki - lasten kotihoidon tuki - kunnan ohjeet.

Waerness, K. (1990). Informal and formal care in old age. What is wrong with the new ideology in Scandinavia today? Teoksessa Ungerson C. (toim.,) Gender and Caring. Work and Welfare in Britain and Scandinavia (s. 110-132). London: Harvester Wheatsheaf.

Valokivi,H. (2008). Kansalainen asiakkaana. Tutkimus vanhusten ja lainrikkojien osallisuudesta, oikeuksista ja velvollisuuksista. Acta Universitatis Tamperensis 1286. Tampere: Tampereen yliopisto.

Valtion lupa-, ohjaus- ja valvontavirastoa valmisteleva ryhmä, Haettu 27.10.2016 osoitteesta: http:// alueuudistus.fi/maakuntauudistus/luova-virasto

Vammaispalvelulaki. Laki vammaisuuden perusteella järjestettävistä palveluista ja tukitoimista 380/1987.

Vanhuspalvelulaki: laki ikääntyneen väestön toimintakyvyn tukemisesta sekä iäkkäiden sosiaali- ja terveyspalveluista 980/2012.

Vaivaishoitoasetus 10/1879.

Valkonen, T. (2017). Sosiaalihuollon oikeussuojajärjestelmä ja asiakkaan tosiasialliset oikeuden- 
saantimahdollisuudet. Teoksessa Nykänen E., Kalliomaa-Puha, L. \& Mattila,Y. (toim.), Sosiaaliset oikeudet - näkökulmia perustaan ja toteutumiseen (s. 166-179). Helsinki: Terveyden- ja hyvinvoinnin laitos.

Vilkko, A., Muuri, A., Saarikalle, K., Noro, A., FinneSoveri, H. \& Jokinen, S. (2014). Läheisavun moninaisuus. Teoksessa Vaarama, M., Karvonen, S., Kestilä, L., Moisio, P. \& Muuri, A. (toim.), Suo- malaisten byvinvointi 2014 (s. 222-237). Helsinki: Terveyden ja hyvinvoinnin laitos.

Zechner, M. (2006). Hoivan paikat transnationaalisissa perheissä. Teoksessa Martikanen, T. (toim.), Ylirajainen kulttuuri. Etnisyys Suomessa 2000luvulla (s. 83-103). Tietolipas 212. Helsinki: Suomalaisen kirjallisuuden seura.

Zechner, M. (2017) Vastuutetut omaishoitajat markkinoilla. Gerontologia, 31(3). 